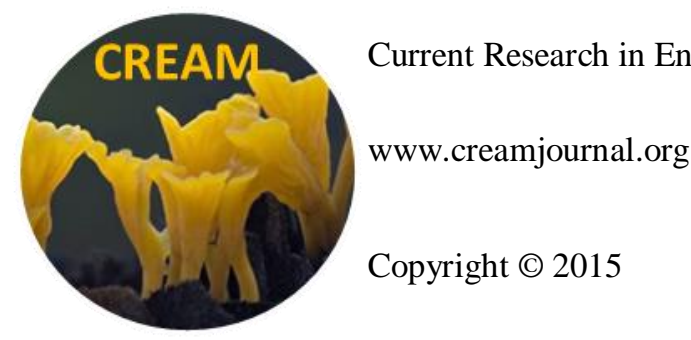

ISSN 2229-2225

Article

CREAM

Doi 10.5943/cream/5/4/10

Online Edition

\title{
Sporidesmium bilgiriense - A new species of microfungi from Western Ghats of India
}

\section{Dubey $R$ and Sengupta $S$}

Botanical Survey of India, Western Regional Centre, Pune, Maharashtra, India

Dubey R, Sengupta S 2015 - Sporidesmium bilgiriense - A new species of microfungi from Western Ghats of India. Current Research in Environmental \& Applied Mycology 5(4), 390-393, Doi 10.5943/cream/5/4/10

\section{Abstract}

A new species of Sporidesmium was discovered during a survey of micro fungi in Biligiri Rangaswamy Temple Wildlife Sanctuary, Karnataka. The new species, Sporidesmium bilgiriense is distinguished from other species of Sporidesmium by having conidia with an apical nodal structure.

Key words - Biligiri Rangaswamy - taxonomy- biodiversity - new species

\section{Introduction}

Biligiri Rangaswamy Temple Wildlife Sanctuary (BRT WLS) is located at the easternmost edge of the Western Ghats of India, between $11^{\circ} \mathrm{N}$ and $12^{\circ} \mathrm{N}$. The sanctuary covers $540 \mathrm{sq} \mathrm{km}$ and is considered a 'bridge' between the Eastern Ghats and the Western Ghats. It contains scrub, dry deciduous, moist deciduous, semi-evergreen, evergreen and shola forests and is likely to harbour rich but still under explored mycobiota (Kumara et al. 2012). In the course of our continuing studies on saprobic microfungi occurring in the area, particularly those hyphomycetous anamorphs associated with dead plant debris, a distinct and unusual species of Sporidesmium Subram. was found. The fungus agrees well with the generic concept originally introduced by Subramanian (1992) for Sporidesmium-like taxa with euseptate conidia and conidiophores with or without proliferating conidiogenous cells. However, it is distinct from previously described species of Sporidesmium in having conidia with 7-9 very dark thick bands, and 2-4 nodal structure at the apical portion, which finally ends in a knob like structure. It is therefore proposed as a new species.

\section{Materials and Methods}

\section{Isolates and morphology}

Samples of dried leaves were placed in paper and aluminium foil bags, taken to the laboratory, and prepared according to Castaneda-Ruiz (2005). The morphological description is based on an examination of material mounted in hydrous lacto phenol and cotton blue. Photomicrographs were taken with the help of a Nikon eclipse $50 \mathrm{i}$ microscope connected to a Nikon DS - Fi 1 camera. Scanning electron microscopic images were also captured using a Zeiss Scanning Electron Microscope Model EVO 18- 12 - 97. The type specimen is deposited in Botanical Survey of India, Western Regional Centre, Pune and the new name is registered with Mycobank. 


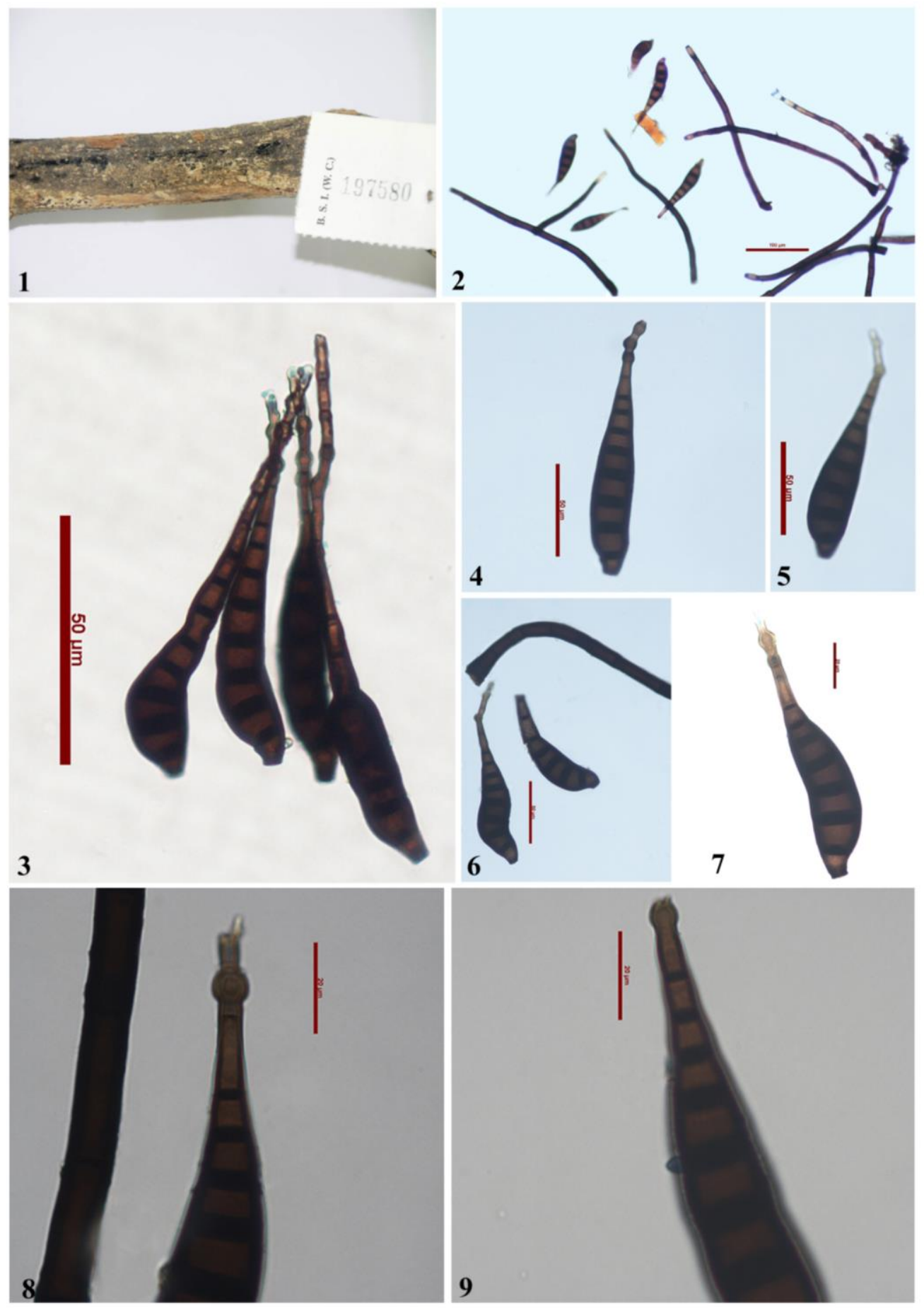

Figs 1 - 9 - Sporidesmium biligiriense sp. nov. 1 Colonies on the host surface. 2 Conidia and conidiophores. $3-7$ Conidia with the apical nodal structure. 8 - 9 Apical nodes. - Bars $2=100$ $\mu \mathrm{m} ; 7-9=20 \mu \mathrm{m}$.

\section{Results}

\section{Taxonomy}

Sporidesmium biligiriense Dubey and Sengupta sp. nov.

Figs 1-23

Mycobank MB814426

Etymology - Species named after the place of collection "Biligiri Rangaswamy Temple Wildlife Sanctuary". 

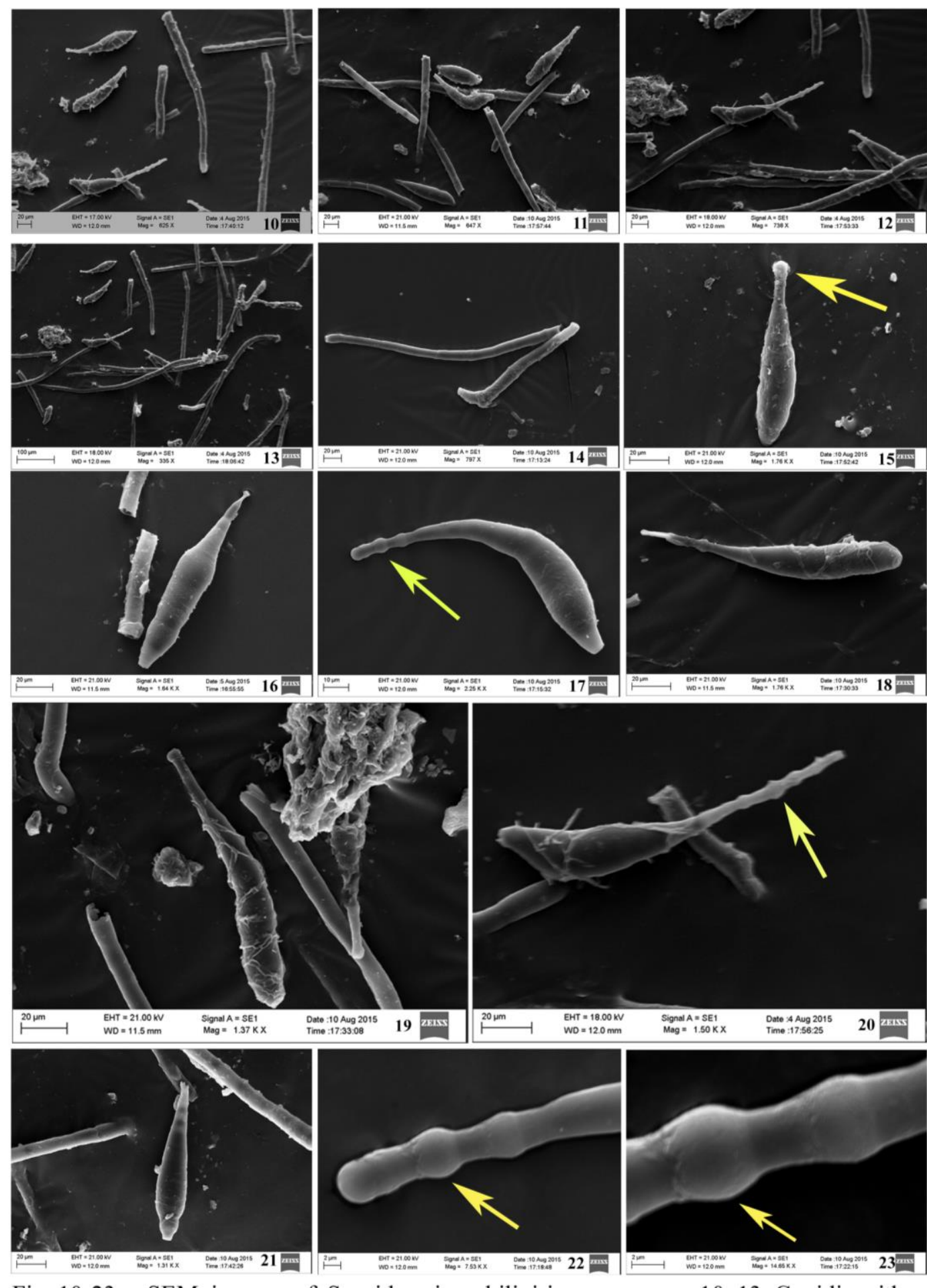

Fig. 10 - 23 - SEM images of Sporidesmium biligiriense sp. nov. $10-13$ Conidia with conidiophores. 14 Conidiophores 15 - 21 Conidia (arrows indicating the apical nodal structure). 22 -23 Apical nodal structure of conidia in higher magnification.

Mycelium mostly immersed. Setae and hyphopodia absent. Conidiophores macronematous, mononematous, single or in groups, unbranched, erect, straight or slightly flexuous, smooth, septate, brown to dark brown, up to $375 \mu \mathrm{m}$ long, $8.5-11 \mu \mathrm{m}$ thick. Conidiogenous cells monoblastic, integrated, non- percurrent. Conidia solitary, dark brown to blackish brown, straight or curved, obclavate to fusiform, base truncate, smooth,7-9 euseptate, with wide dark bands at the 
septa, $85-155 \times 22-28 \mu \mathrm{m}$, tapering to $5-6 \mu \mathrm{m}$ near the apex and $7.5-8.5 \mu \mathrm{m}$ at the base, $2-4$ node-like structures present in the pale brown apical part.

Teleomorph - Unknown.

Known distribution - Biligiri Rangaswamy Temple Wildlife Sanctuary, Karnataka.

Material examined - India: Karnataka, Biligiri Rangaswamy Temple Wildlife Sanctuary, dead unidentified stem, 2 Oct 2014, Shreya Sengupta, holotype, BSI 134286.

\section{Discussion}

The genus Sporidesmium was established by Link in 1980 with type species S. atrum Link. The key features of $S$. biligiriense are simple septate conidiophores, and the solitary, gangliar, thick-walled euseptate conidia. Although the conidiophores of the new species do not proliferate, those of some species may proliferate per currently or irregularly (Subramanian 1992). Mycobank and Index Fungorum database record a total of 472 species of Sporidesmium. The present species differs from other species of Sporidesmium in having 7-9 wide dark bands at the septa and 1-4 nodes in the pale brown apical part of the conidia. The specimen is therefore described as a new species. The present species resembles S. crassisporum M.B. Ellis (EEllisembia crassispora (M.B. Ellis) Subram.) in having dark band in the conidia, but the conidia of $S$. crassisporum are distoseptate, verruculose and larger $(100-250 \times 18-30 \mu \mathrm{m})$ and are not nodulated at the apical portion. In addition, the conidiophores of $S$. crassisporum have 0-3 annellations, while the conidiophores of $S$. biligiriense are non-annellated.

\section{Acknowledgements}

The authors thank Dr. Paramjeet Singh, Director, Botanical survey of India, for his kind support and providing all the research facilities. They are also grateful to the Head of the office, Botanical Survey of India, Western Regional Centre, Pune, for his kind support and encouragement. Forest department of Karnataka state is thankfully acknowledged for their help and support. Ministry of Environment, Forest and Climate Change, New Delhi, is acknowledged for financial assistance.

\section{References}

Castañeda-Ruiz RF. 2005 - Metodología em el estudio de los hongosanamorfos. Anais do V Congresso Latino Americano de Micología. Brasilia. p. 182 - 183.

Kumara HN, Rathnakumar S, Sasi R, Singh M. 2012 - Conservation status of wild mammals in Biligiri Rangaswamy Temple wildlife sanctuary, the Western Ghats, India. Current Science. 103: 933-940.

Subramanian CV. 1992 - A reassessment of Sporidesmium (hyphomycetes) and some related taxa. Proceeding of the Indian Academy of Sciences (Plant Sciences). 58 (4): 179-190. 